\title{
NEURO-FUZZY MODELING OF EYEBALL AND CREST TEMPERATURES IN EGG- LAYING HENS
}

\author{
Ana C. de S. S. Lins ${ }^{1 *}$, Dian Lourençoni ${ }^{1}$, Tadayuki Yanagi Júnior ${ }^{2}$, \\ Isadora B. Miranda ${ }^{1}$, Italo E. dos A. Santos ${ }^{1}$ \\ ${ }^{1 *}$ Corresponding author. Universidade Federal do Vale do São Francisco/ Juazeiro - BA, Brasil. \\ E-mail: ana_carolina_lins@ @otmail.com | ORCID ID: 0000-0002-9182-8625
}

\section{KEYWORDS}

Neuro-fuzzy, Thermography, Poultry farming, Simulation, Artificial intelligence.

\begin{abstract}
Considering the challenges faced by poultry farming, this study aimed to develop a neurofuzzy model to predict eyeball and crest temperatures of egg-laying hens based on environmental conditions (dry bulb temperature and relative humidity). To develop the models and simulations, Matlab's Fuzzy Toolbox ${ }^{\circledR}$ (Anfisedit) was used. Different configurations were used for each of the several neuro-fuzzy models developed. Eyeball temperature (ET) and chicken crest temperature (CCT) were simulated from the developed neuro-fuzzy models, and the obtained results were validated with the variables collected experimentally with the aid of recorder sensors and an infrared thermographic camera. The proposed neuro-fuzzy models allow the accurate estimation of ET and CCT of two lineages of egg-laying hens raised in conventional aviaries, thus helping in decision-making for better animal welfare.
\end{abstract}

\section{INTRODUCTION}

Poultry farming is one of the most important activities of the agricultural sector in Brazil (Coelho et al., 2015). The environment of the rearing system is one of the main factors that cause losses in production (Oliveira et al., 2014). When thermal comfort limits are exceeded, the energy that should be used for egg production is spent in thermoregulatory processes. This compensation is part of the homeostasis mechanisms of homeotherms (Lara \& Rostagno, 2013; Lourençoni et al., 2019). In this context, thermal control of the environment is crucial for broilers, which develop their maximum genetic potential in an optimal temperature range (Abreu et al., 2015).

Chickens release heat by breathing and through body surfaces that have no feathers, such as the crest (Welker et al., 2008). The surface temperature of an animal can be a quick response to thermal discomfort caused by the environment (Bahuti et al., 2018). Stewart et al. (2010) concluded that ocular temperature is the most reliable parameter to measure the surface temperature of cattle, and it is directly correlated with pain and thermal stress.

A new concept, "precision livestock farming," emerged with the modernization of animal husbandry. It assists with decision-making as well as real-time monitoring and reduces losses (Nascimento et al, 2011). Thus, computational modeling tools, such as fuzzy logic and neural networks, have been widely applied in this context (Schiassi et al., 2014; Schiassi et al., 2015; Yanagi Junior et al., 2012). According to Putti (2015), computational modeling provides more accurate results than regression modeling.

Intelligent systems based on fuzzy logic can work with inaccurate information and translate it into a mathematical language that is easily executed on a computer. Fuzzy logic can be used as an aid to decisionmaking, helping in the control of the thermal environment within poultry facilities (Campos et al., 2013; Oliveira et al., 2018). The rule base, which relates the system's input variables with the output variables, is designed according to expert opinions; therefore, it might present a subjective aspect to modeling (Mirzaee-Ghaleh et al., 2015).

Based on the assumption that ambient temperature and humidity influence the productive development of egglaying hens, the use of artificial neural networks (ANNs) can be useful for predicting zootechnical responses of birds, thus helping in decision-making for the thermal comfort and welfare conditions of birds (Ferraz et al., 2014).

\footnotetext{
${ }^{1}$ Universidade Federal do vale do São Francisco/ Juazeiro-BA, Brasil.

${ }^{2}$ Universidade Federal de lavras/ Lavras-MG, Brasil.
}

Area Editor: Héliton Pandorfi

Received in: 9-18-2020

Accepted in: 11-26-2020 
Considering the challenges faced by poultry farming, this study aimed to develop a neuro-fuzzy model for predicting the eyeball temperature (ET) and chicken crest temperature (CCT) of egg-laying hens based on environmental conditions of dry bulb temperature (DBT) and relative humidity $(\mathrm{RH})$.

\section{MATERIAL AND METHODS}

The procedures performed in this experiment were approved by the Committee on Ethics in the Use of

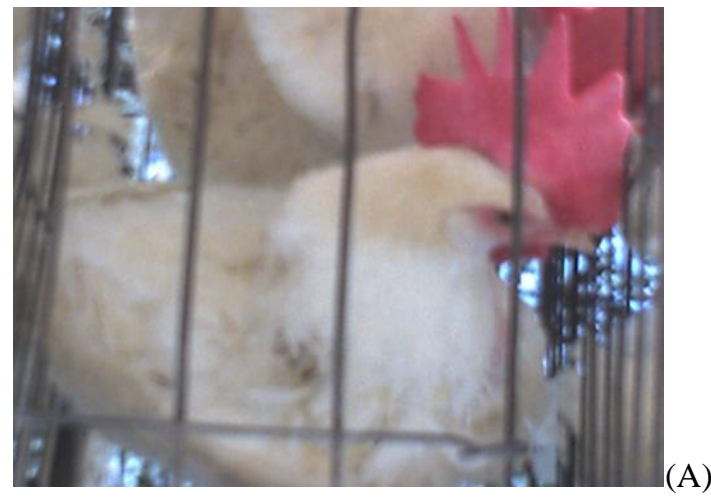

(A)

FIGURE 1. Hyline W-36 (A) and Dekalb Brown (B).

The DBT and RH were measured every 15 min using recorder sensors (Onset HOBO® TEMP/RH, accuracy of \pm $0.35{ }^{\circ} \mathrm{C}$ for temperature and $\pm 5 \%$ for relative humidity), located close to the birds and at a medium height of the cages. The surface temperature of the hens was also recorded using an infrared thermographic camera (Fluke Ti 55ft; Fluke Corporation, Everett, WA) with an emissivity set configured between 0.95 and 0.98 (Salles et al., 2016). The images were collected three times a day $(9,13$, and 17 h) for 25 weeks in each shed, with two birds per period, for a total of 125 hens per aviary. The images were then analyzed using the Fluke SmartView 3.0 software, and the ET and CCT temperatures could be obtained (Figure 2).

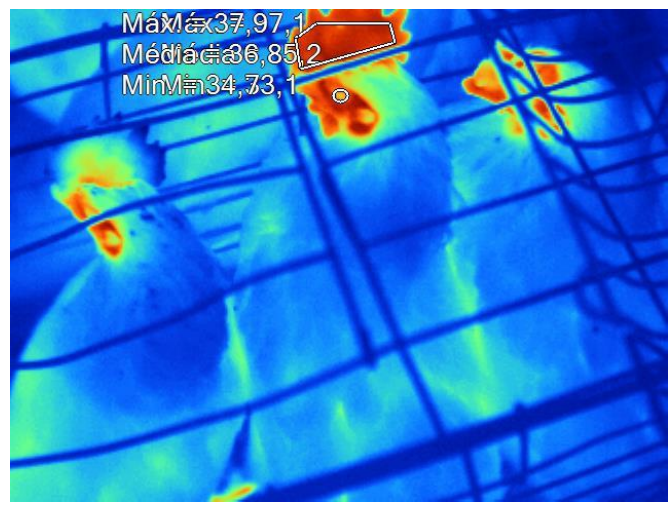

FIGURE 2. Thermographic image.

The neuro-fuzzy-based models were constructed, adjusted, and validated from the database collected from the
Animals, Federal University of Lavras, protocol no. 026/12. The experiment was conducted in two conventional $7 \mathrm{~m} \times$ $120 \mathrm{~m}$ aviaries, with an asbestos cement roofing tile, a height of $2.50 \mathrm{~m}$, and an east-west orientation. At the beginning of the experiment, egg-laying hens (Figure 1) of the Hyline W-36 (A) and Dekalb Brown (B) lineages, aged 17 weeks and 71 weeks, respectively, were housed separately in conventional aviaries. During the experimental period, the birds received water and feed $a d$ libitum, and their eggs were collected twice a day.

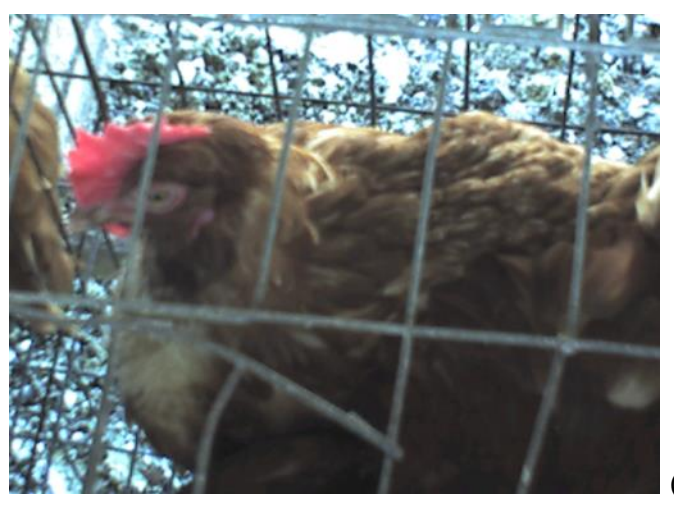

(B) sheds. DBT and RH were used as input variables, and ET and CCT were set as output variables.

For each data set, three subgroups (training, validation, and testing) were assigned to develop the neurofuzzy system, and $70 \%$ of the set was used for training while $30 \%$ for validation and testing. A neuro-fuzzy system was derived from the Takagi-Sugeno fuzzy inference system (FIS). In this system, the input and output dispositions are based on rules; therefore, the answers are elaborated by piecewise functions (not fuzzy) (Takagi \& Sugeno, 1985).

To develop the models and simulations, Matlab® Fuzzy Toolbox ${ }^{\circledR}$ software version 7.13.0.564 (R2011b) was employed, with Anfisedit. Different configurations were utilized for the development of several neuro-fuzzy models. The types of relevance functions (Gaussian, triangular, and trapezoidal), number of training seasons, and optimization methods (retropropagation or hybrid) were tested. Based on the tests, the model with the lowest training error and no internal output errors in its sets were selected.

The observed $(\mathrm{O})$ and predicted $(\mathrm{P})$ values were plotted. From the resulting dispersion diagram, a linear model was created, and the intercept and slope were determined. This model was used for observing the general behavior of the predictions and their deviations from the ideal forecast $(\mathrm{O}=\mathrm{P})$.

The ET and CCT were simulated from the neurofuzzy models developed, and the results were validated with the variables collected experimentally using the following equations:

Mean error or tendency $=M E=$ Systematic error $=$ Bias $=\frac{1}{n} \sum_{i=1}^{n}\left(P_{i}-O_{i}\right)$,

Absolute error $=M A E=\frac{1}{n} \sum_{i=1}^{n}\left|P_{i}-O_{i}\right|$ 


$$
\begin{aligned}
& \text { Mean square error }=M S E=\frac{1}{n} \sum_{i=1}^{n}\left(P_{i}-O_{i}\right)^{2} \\
& \text { Root mean square error }=R M S E=\sqrt{\frac{1}{n} \sum_{i=1}^{n}\left(P_{i}-O_{i}\right)^{2}} \\
& \text { Mean absolute percentage error }=M A P E=\frac{1}{n} \sum_{i=1}^{n}\left|\frac{O_{i}-P_{i}}{O_{i}}\right| \cdot 100, \\
& \text { Coefficient of determination }=R^{2}=1-\frac{\sum_{i=1}^{n}\left(P_{i}-\overline{0}\right)^{2}}{\sum_{i=1}^{n}\left(O_{i}-\overline{0}\right)^{2}}, \\
& \text { Nash - Sutcliffe efficiency index }=N S E=1-\left[\frac{\sum_{i=1}^{n}\left(P_{i}-O_{i}\right)^{2}}{\sum_{i=1}^{n}\left(o_{i}-\overline{0}\right)^{2}}\right]
\end{aligned}
$$

Where:

$\mathrm{P}_{\mathrm{i}}$ is the ith predicted value $(\%)$;

$\mathrm{O}_{\mathrm{i}}$ is the ith observed value $(\%)$;

$\mathrm{n}$ is the total number of samples, and

$\overline{0}$ is the mean of the observed values (\%). For NSE see (Nash \& Sutcliffe, 1970).

These equations are intended to evaluate the model's ability to predict ET and CCT for all possible combinations of the input data; thus, they can be used as a tool to assist in decision-making regarding the thermal comfort and welfare conditions of egg-laying hens.

\section{RESULTS AND DISCUSSION}

Figure 3 shows the dispersion graphs for ET and $\mathrm{CCT}$ respectively of predicted values $(\mathrm{P})$ from neuro-fuzzy simulations (y-axis) at experimentally observed values $(\mathrm{O})$ (x-axis). The diagonal lines represent the ideal cases, in which $\mathrm{P}=\mathrm{O}$.
It is observed that there was a correlation between the predicted and observed temperatures, with coefficients of determination of 0.68 and 0.66 for ET and CC, respectively. This result can be explained by the fact that, in egg-laying hens, the surface temperature variation is high mainly due to race and environmental factors, and these animals present adjustments in peripheral circulation as a form of heat dissipation (Soerensen \& Pedersen, 2015). Heat stress affects the hens because their feathers prevent the dissipation of internal heat; therefore, it increases the blood flow to the peripheral areas, resulting in heat exchange with the environment (Coelho et al., 2015).

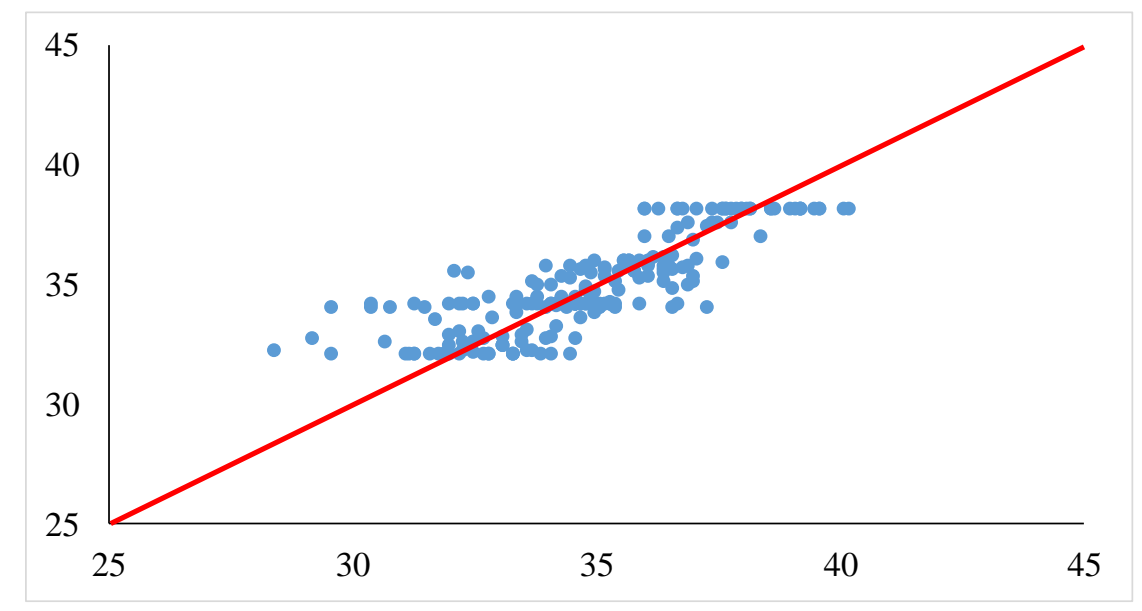

(A) 


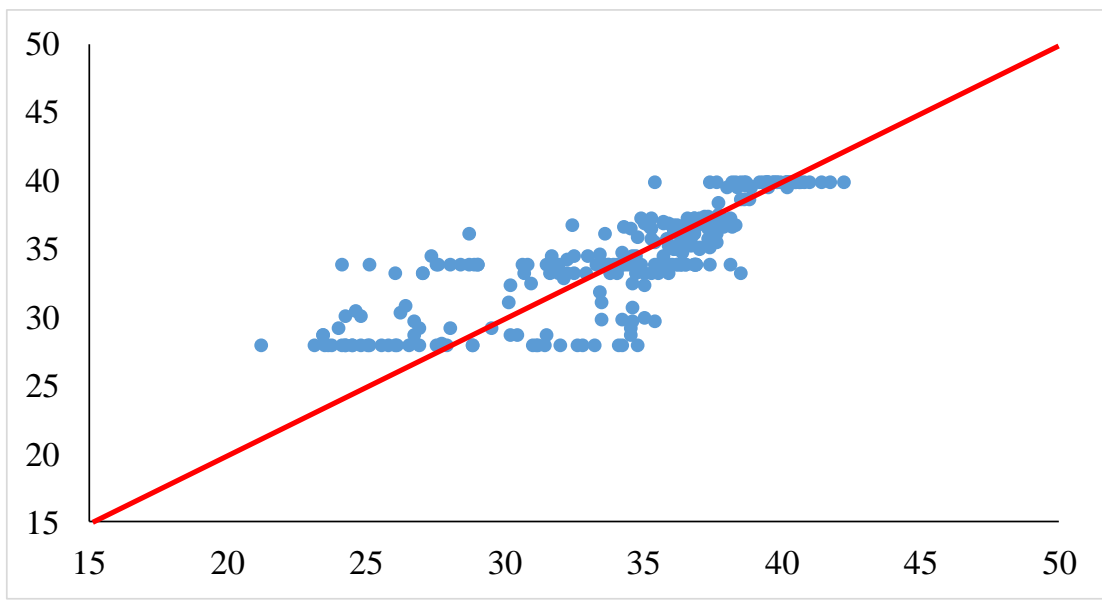

(B)

FIGURE 3. Dispersion diagrams for eyeball temperature $\left(\mathrm{ET},{ }^{\circ} \mathrm{C}\right)(\mathrm{A})$ and chicken crest temperature $\left(\mathrm{CCT},{ }^{\circ} \mathrm{C}\right)(\mathrm{B})$ for NeuroFuzzy simulations.

The statistical indices of adequacy and accuracy of the models for the responses of ocular and crest temperatures obtained through the neuro-fuzzy model are shown in Table 1.

TABLE 1. Statistical indices to verify the adequacy of adjustment and accuracy of neuro-fuzzy models for ET and CCT.

\begin{tabular}{ccccccc}
\hline \multirow{2}{*}{ Variables } & \multicolumn{7}{c}{ Performance indices } \\
\cline { 2 - 7 } & ME=BIASBIAS & MAE & MSE & RMSE & MAPE & NSE \\
\hline $\mathrm{T}_{\mathrm{o}}$ & 0,0006 & 0,9817 & 1,7908 & 1,3382 & 2,9027 & $-0,0286$ \\
$\mathrm{~T}_{\mathrm{c}}$ & $-0,0019$ & 1,9577 & 7,2906 & 2,7001 & 6,3080 & $-0,0245$ \\
\hline
\end{tabular}

From the results of ME or BIASBIAS, although the individual errors of the system are not considered, it is possible to realize that both prediction models for ET and CCT present a low difference between the results. A low dispersion of the observed and predicted values can also be deduced when the values of MAE, MSE, and RMSE are close to zero. The dispersion of the observed and predicted values was slightly higher for the model that predicted the CCT.

The MAPE, which is widely used to indicate precision in simulations, was $2.9 \%$ and $6.3 \%$ for ET and CCT, respectively. These values are considered acceptable in case studies, proving the accuracy of the two proposed models.

The values of NSE, commonly used for the performance evaluation of models hydrological studies (Tongal \& Booij, 2018), were approximately -0.02 for both ET and CCT. These results reiterate the adaptive capacity of the models for the simulation of ET and CCT.

Overall, the statistical indicators ME (=BIASBIAS), MAE, MSE, RMSE, MAPE, and NSE presented a better fit in the prediction of ET. This can be explained by the high variation in the temperature of the crest (CCT), which is one of the main forms of heat exchange with the environment (Nascimento et al., 2013).

\section{CONCLUSIONS}

The proposed neuro-fuzzy models allow the accurate estimation of the eyeball temperature (ET) and the chicken crest temperature (CCT) of two lineages of egg-laying hens raised in conventional aviaries, thus helping in decisionmaking for better animal welfare.

\section{ACKNOWLEDGEMENTS}

The authors express their gratitude to FAPEMIG, CAPES and CNPq for their support to this research.

\section{REFERENCES}

Abreu LHP, Yanagi Junior T, Fassan, ÉJ, Campos AT, Lourençoni D (2015) Modelagem fuzzy do desempenho de frangos de corte, criados de 1 a 21 dias, sujeitos a estresse por calor. Engenharia Agrícola 35: 967-978. DOI: https://doi.org/10.1590/1809-4430-Eng.Agric.v35n6p967978/2015

Bahuti M, Abreu LHP, Yanagi Junior T, Lima RR, Campos AT (2018) Desempenho de sistemas de inferência fuzzy para prever a temperatura de superfície de frangos de frango. Engenharia Agrícola 38: 813-823. DOI: https://doi.org/10.1590/1809-4430-eng.agric.v38n6p813$823 / 2018$

Campos AT, Castro JO, Schiassi L, Yanagi Junior T, Pires MFÂ, Mattioli CC (2013) Prediction of free-stall occupancy rate in dairy cattle barns through fuzzy sets. Engenharia Agrícola 33: 1079-1089. DOI: https://doi.org/10.1590/S0100-69162013000600001

Coelho DJR, Tinoco IFF, Vieira MFA, Mendes MASA, Sousa FC, França LGF (2015) Mapeamento do ambiente térmico de aviários de postura abertos em sistema vertical de criação. Revista Brasileira de Engenharia Agrícola e Ambiental 19: 996-1004. DOI: https://doi.org/10.1590/18071929/agriambi.v19n10p996-1004 
Ferraz AS, Soares VP, Soares CPB, Ribeiro CAAS, Binoti DHB, Leite HG (2014) Estimativa do estoque de biomassa em um fragmento florestal usando imagens orbitais. Floresta e Ambiente 21:286-296. DOI: https://doi.org/10.1590/2179-8087.052213r

Lara LJ, Rostagno M H (2013) Impact of heat stress on poultry production. Animals 3: 356-369. DOI:

https://doi.org/10.3390/ani3020356

Lourençoni D, Paulo AG, Yanagi Junior T, Campos AT, S. Yanagi NM (2019) Pertinence curves in fuzzy modeling of the productive responses of broilers. Engenharia Agrícola 39: 265-271. DOI: https://doi.org/10.1590/1809-4430eng.agric.v39n3p265-271/2019

Oliveira DL, Nascimento JWB, Camerini NL, Silva RC, Furtado DA, Araujo TGP (2014) Desempenho e qualidade de ovos de galinhas poedeiras criadas em gaiolas enriquecidas e ambiente controlado. Revista Brasileira de Engenharia Agrícola e Ambiental 18: 11861191. DOI: https://doi.org/10.1590/1807-

1929/agriambi.v18n11p1186-1191

Oliveira RF, Ferreira RA, Abreu LHP, Yanagi Júnior T, Lourençoni D (2018) Estimation of respiratory frequency and rectal temperature on pigs in heat stress by fuzzy logic. Engenharia Agrícola 38: 457-470. DOI: https://doi.org/10.1590/1809-4430-eng.agric.v38n4p457$470 / 2018$

Mirzaee-Ghaleh E, Omid M, Keyhani A, Dalvand MJ (2015) Comparação de controladores fuzzy e on / off para o gerenciamento de clima interno no inverno em um aviário modelo. Computers and Electronics in Agriculture 110: $187-195$.

Nascimento GR, Pereira DF, Näas I.A, Rodrigues LHA (2011) Índice fuzzy de conforto térmico para frangos de corte. Engenharia Agrícola 31: 219-229. DOI: https://doi.org/10.1590/S0100-69162011000200002

Nascimento ST, Silva IJO, Maia ASC, Castro AC, Vieira FMC (2013) Mean surface temperature prediction models for broiler chickens a study of sensible heat flow. International Journal of Biometeorology 58: 195-201. DOI: https://doi.org/10.1007/s00484-013-0702-7.

Nash JE, Sutcliffe JE (1970) River flow forecasting through conceptual models: Part I. A discussion of principles. Journal Hydrology 10: 282-290. DOI: https://doi.org/10.1016/0022-1694(70)90255-6

Putti FF (2015) Análise dos indicadores biométricos e nutricionais da cultura da alface (Lactuca sativa L.) irrigada com água magneticamente utilizando modelagem fuzzy. Tese Doutorado, Botucatu, Faculdade de Ciências Agronômicas, Universidade Estadual Paulista.
Salles MSV, Silva SC, Salles FA, Jr LCR, El Faro L, Mac Lean PAB, Oliveira CEL, Martello LS (2016) Mapping the body surface temperature of cattle by infrared thermography. Journal of Thermal Biology 62: 63-69. DOI: https://doi.org/10.1016/j.jtherbio.2016.10.003

Schiassi L, Yanagi Júnior T, Damasceno FA, Saraz AO, Amaral AG (2014) Índice de conforto térmico-acústico para trabalhadores de avicultura utilizando modelagem fuzzy. Revista de Pesquisa e Aplicações de Engenharia Ghaziabad, 4: 60-64.

Schiassi L, Yanagi Júnior T, Reis GM, Abreu LHP, Campos AT, Castro JO (2015) Modelagem fuzzy aplicada a avaliação do desempenho dos frangos de corte. Revista Brasileira de Engenharia Agrícola e Ambiental 19: 140160. DOI: https://doi.org/10.1590/18071929/agriambi.v19n2p140-146

Soerensen DD, Pedersen LJ (2015) Infrared skin temperature measurements for monitoring health in pigs: a review. Acta Veterinaria Scandinavica 57:1-11. DOI: https://doi.org/10.1186/s13028-015-0094-2

Stewart M, Stafford KJ, Dowling SK, Schaefer AL, Webster JR (2008) Eye temperature and heart rate variability of calves disbudded with or without local anaesthetic. Physiology \& Behavior 93(4-5):789-797. DOI: https://doi.org/10.1016/j.physbeh.2007.11.044.

Stewart M, Webster JR, Stafford KJ, Schaefer AL, Verkerk GA (2010) Effects of an epinephrine infusion on eye temperature and heart rate variability in bull calves. Journal of dairy science 93(11): 5252-5257. DOI: 10.3168/jds.2010-3448.

Takagi T, Sugeno M (1985) Fuzzy identification of systems and its applications to modeling and control, IEEE Transactions on Systems, Man, and Cybernetics 15: 116132. DOI: https://doi.org/10.1109/TSMC.1985.6313399

Tongal H., Booij MJ (2018) Simulation and forecasting of streamflows using machine learning models coupled with base flow separation. Journal of hydrology 564: 266-282. DOI: https://doi.org/10.1016/j.jhydrol.2018.07.004

Yanagi Júnior T, Schiassi L, Abreu LHP, Barbosa JA, Campos AT (2012) Procedimento fuzzy aplicado à avaliação da insalubridade em atividades agrícolas. Engenharia Agrícola 32:423-434. DOI: https://doi.org/10.1590/S0100-69162012000300002

Welker JS, Rosa APM, Daniella JM, Lizandra P, Catelan F, Uttpatel R (2008) Temperatura corporal de frangos de corte em diferentes sistemas de climatização. Revista Brasileira de Zootecnia 37(8): 1463-1467. DOI: https://doi.org/10.1590/S1516-35982008000800018 